SZALAI JÚLIA ${ }^{1}$

A DAL DIADALA

(2. RÉSZ)

https://doi.org/10.18030/socio.hu.2021.4.254

Az esszé első része a folyóirat előző lapszámában jelent meg, ide kattintva olvasható:

A dal diadala (1. rész).

\title{
MARK KNOPFLER
}

Mark Freuder Knopfler Miskolcról a zsidóüldözések és baloldali politikai részvételének megtorlása elől 1938-ban elmenekült építészmérnök apa és Észak-Angliából származó angoltanárnő anya gyermekeként látta meg a napvilágot Glasgow-ban 1949-ben. Középső nevét az emlékőrzés jegyében kapta: a Freuderek apai nagyszülei voltak, akiknek sorsáról nem szól semmilyen nyilvános emlékezés. Így nem tudjuk, hogy túlélték-e a holokausztot, s ha igen, a szétszóródott családban őket hová vetette az élet. Vajon Magyarországon maradtak-e vagy kivándoroltak, s ha igen, hová? Amennyire követhető, a családi szálak eléggé szétzilálódtak, és így Erwin Knopfler, Mark apja nemigen ápolta a rokoni kapcsolatot Franciaországban letelepedett öccsével, s vélhetőleg még kevésbé a Magyarországon maradt rokonokkal. A három Knopfler-gyerek - Ruth, a fiúk nővére, Mark és David - angol középosztályi normák szerint nevelkedtek, a korszakban újítónak számító liberális nevelés elveivel és gyakorlatával. Az elemi életrajzi tényen túl, a zsidó hovatartozás nem kerül elő az életútinterjúkban. Egyetlen finom utalásként egy klip beszél erről: a Mark Knopflert fontos helyszínein fényképező sorozat egyik darabján egy közeli zsidó temetőben a borostyánnal benőtt sírok előtt guggolva látjuk őt. Az üzenet világos: a származási, vallási identitás a magánszférába tartozik, ott megvan a maga privát fontossága; azonban - mint egy másik klip tanúsítja - a publikus és munkakapcsolatokban semmi kitüntetettsége nincs egy vagy más zenésztárs katolicizmusával vagy ateizmusával szemben.

Mark körülbelül tíz éves, amikor a család elhagyja Glasgow-t, és átköltözik az édesanya szülővárosába, Newcastle-ba. A csere nem kis jelentőségú. Newcastle az ötvenes, hatvanas években a korabeli jazz és rockzene fellegvára, folyamatosan biztosítva a fiatal tehetségekből álló zenekarok kirajzását az ország minden tájára. A zenével átitatott környezetben a kiskamasz Mark már nemcsak passzív hallgatóként akarna részt venni, hanem álmai között egy saját rockzenekar felállítása szerepel. Ehhez azonban az első, hogy az embernek legyen egy gitárja, és megtanuljon azon játszani. A szülők pénztárcájából nem futotta magas klasszisra, de egy jószolgálatot tett német másolati példány beszerzésére igen. Külleme szerint ez volt az a piros gitár, ami Mark Knopfler zenei pályáját elindította. Szolid, de megbízható hangszer volt, amit barkácsolt erősítővel igazi elektromos gitárrá lehetett átvarázsolni. Éjszakába nyúló próbálgatásokkal ezen a gitáron alakult ki Knopfler sajátos játékstílusa, amiről ma, világklasszisként is úgy beszél, mint ami egy hivatásos gitártanár szemében maga a rémálom. Nem szabályosak az akkordfogásai, és ugyan nem egyedülálló, de mégis ritkaságszámba megy az ujjakkal való pengetés, azaz a kis pengető lapocska teljes mellőzése. Mindemellett zenei ízlésből és tudásból szerencsésen

1 Szociológus, az MTA levelező tagja. 
nagy pakkot kapott. Nagybátyja zongorajátékát hallgatva, megismerkedik az amerikai jazz alapjaival és olyan nevekkel, mint Chet Atkinsé vagy Bob Dylané. Lemezekről és magnókazettákról tanul Hank Marvintól, a Shadows-együttes vezető gitárosától, és ugyancsak zenekedvelő osztálytársai révén ismerkedik meg Elvis Presley magával sodró dalaival. A kamaszkori program világos: mindent meg kell tanulni ezektől a kiemelkedő zenészektől, amit csak lehet, majd továbblépni és saját zenét alkotni. De a főállású zenészségig még évek telnek el. Mark Knopfler a középiskola után előbb egy évig újságírást tanul, majd újságíróként keresi a kenyerét, hogy utóbb visszatérjen az egyetemi világba, ahol angol nyelvből és irodalomból szerez diplomát. Mindeközben kis zenekart szervez, amellyel nagy slágerek átültetésével nem kevés sikert arat. De miközben polgári foglalkozását gyakorolja, a dalok - ahogy ő fogalmazza - lökik tovább a zene felé. Öccsével és egy barátjukkal összeköltözve, folyamatosan gyakorolnak és tanulnak, mígnem ezen az alapon 1977-ben megalakítják a Dire Straits együttest, amelynek Mark Klopfer nemcsak a vezetője lesz, hanem egyúttal a fő dalszövegírója és vezető gitárosa is. Az együttes a szó szoros értelmében berobban a zenei világba. Összetett dallamviláguk és a tömör szövegek láttató ereje csillagként felívelő pályára teszi a zenekart, amely néhány éven belül milliószámra adja el lemezeit. Nincs azonban reflektálás a korszak nagy társadalmi mozgásaira, így nincs kapcsolódás a hippimozgalomhoz sem. A fő törekvés a professzionalizmus kicsiholása, a kiemelkedés a kis klubok és pubok világából. Ez a törekvés azonban nem egykönnyen valósítható meg: nincs mögötte stúdió, és nincsenek mögötte ügyes és hatékony menedzserek és producerek sem. Az együttes amerikai körútja ugyanakkor ezt is meghozza. Kilépve a világ legnagyobb és éles versenyhelyzetek sorát kihívó zenei piacára, Amerikában születnek meg az első bemutatkozó demólemezek, amelyek megnyitják az utat a nagy lemezgyárak felé. A Dire Straits hatalmas nemzetközi sikert arat, és esténként 70-80 ezer ember előtt koncertezik. Fő dalukból, a „Sultans of Swing”-ből rekordsikert elérő szám lesz, amely ott van minden jegyzett lemezlista élén. Az élet humora, hogy ez a dal éppen az ismeretlenségbe süllyedő dilettantizmust kritizálja, azt, amit a fiatal zenészek a leginkább el kívántak kerülni. „És Harry nem bánja, ha nem uralja a színpadot,/ van nappali állása, rendben megvan vele./ És játszani tudja a Honky Tonkot, mint bármi mást is,/ péntek éjszakára tartogatva,/ a Szultánokkal, a swing szultánjaival” („Sultans of Swing”). A dal és egyidejűleg elkészült párjai szinte automatikusan tolják az együttest a könnyúzenei nagyipar irányába.

A koncertjeiken jelenlévő tízezrek már átláthatatlan és lélektanilag befoghatatlan tömeget alkotnak, s bár mindez nagy hírnevet és sok pénzt hoz, Mark Knopfler egyre feszélyezettebbé válik ebben a helyzetben, egyre kevésbé érzi magáénak az egész elrendezést. Az első attak testvérének 1980-as kiválása a zenekarból, aki éppen egy lemezfelvétel közepén fordul bátyjával szembe, a demokratikus vezetés és a szerepek egyenlőbb elosztásának hátrahagyását vágva a szemébe. A rivalizálásra épülő viszony úgy megromlik, hogy egy életre beszüntetik a beszélőviszonyt is. Csak most, az öregedés éveiben áll David Knopfler elő azzal, hogy valamikor még szeretne a bátyjával játszani - de ez ma már valószínúleg csak beteljesületlen utópia marad. David kiválását gyakori zenészcserék követik, de az együttes kezdeti bensőségessége soha többé nem áll helyre. Mindazonáltal a Dire Straits sikerútja folytatódik, sőt, népszerúségük egyre feljebb ível. De minél nagyobb a siker, annál nagyobb az ár, amit fizetni kell érte: a zenekar nem ura többé sem a lemezeinek, sem a koncertkörútjainak, sem a szereplés más formáinak. Mark Knopfler egy évtized elteltével világosan látja: ez nem az ő világa, és ki kell lépnie belőle. A Dire Straits tulajdonképpen elhal: miközben nyilvánosan nem mondták ki a felbomlást, 1995-re az együttes gyakorlatilag eltúnik a színről.

Mark Knopfler szólókarrierbe kezd, s ezt mindvégig azzal indokolta, hogy csak így teremthette újra azt az intimitást a közönségével, ami zenéinek alapszövete, és amit pszichológiailag is kezelni tud. A legfontosabb dalok, a közönség nagy kedvencei túlélték a váltást, és Mark Knopfler átdolgozott hangszerelésben és szólóénekre átformálva mindmáig músoron tartja azokat. De a nagybani évek sem voltak haszontalanok. Mark 
Knopfler megtapasztalhatta zenéjük és előadói stílusuk közönség- és közösségteremtő erejét. Anélkül, hogy maguk betársultak volna a hippimozgalomba, zenéjük a hippitalálkozók nagy kedvence lett, de magáénak tudta azt a beilleszkedett, polgári karrierre és polgári életformára aspiráló, megállapodottabb ifjúság is. És a szólókarrier idején ugyanez folytatódott: a zenésszel együtt idősödő közönség radikálisabb és beilleszkedőbb rétegei egyaránt a magukénak érezték és vallották Mark Knopfler zenéjét. Ez az átütő varázserő több forrásból táplálkozott. A zenei alapokat a nagy invencióval összeötvözött country- és jazzmuzsika, a társuló rock 'n' roll és a mélyebb gyökerekben fellelt ősi népzene, valamint a kelta zene szálai jelentették. A forrásokról Mark Knopfler évekig tartó stúdiumokat folytatott, amihez igen megtermékenyítően társult közelebbi kapcsolata az amerikai countryval - mindenekelőtt az őt közös zenélésre meghívó Chet Atkins tolmácsolásában. Noha Mark Knopfler nemegyszer csipkelődött Atkins „ódivatúságán”, valójában sok évvel Atkins halála után is egyik legfontosabb iskolájaként emlegette, amit a mesternek tekintett baráttól tanult. Nem is véletlen, hogy a következő években countrymuzsikusok kísérőjeként látjuk viszont. Így játszik együtt a rockot és a countryt ötvöző Everly Brothersszal, a country modernebb útját járó, hillbillyt zenélő Kris Kristoffersonnal, vagy az ugyancsak a countryalapokat is felhasználó Van Morrisonnal - és mindenekelőtt a rockot, bluest és countrygyökereket ötvöző Bob Dylannel. A zenei anyagnak és a zenélés módjának egyaránt adózó csodálat ezeket a vendégkoncerteket szervesen beillesztette Mark Knopfler pályaútjába.

A zene mellett egyenlő fontossága van a szövegnek. A sokszor írói pontossággal megrajzolt környezeti képek mindig emberi viszonyokat kereteznek: a bajtársak nyomorúságát a háborúban, a pénzemberek érzéketlenségét a szegények és a küszködő kispolgári egzisztenciák iránt, a férfi-nő kapcsolatok melegségét és buktatóit, a nagyemberek kicsinyességét vagy az apa-fiú kapcsolat férfiszolidaritását és feszültségeit. Ezekben az életképekben vissza-visszatérő elem a csaknem giccses elolvadás és az irónia vegyítése, ami egyrészt új síkra emeli a mondandót, másrészt a zene minden hallgatóját önmérsékletre és kárörvendő gondolatainak feladására inti: senki soha nem lehet teljesen biztos a maga igazában - akár mondja, akár cselekszi azt. Mások másfajta látószögéből nézve elbukhat, vagy legalábbis önkritikus kérdéseket kell feltennie önmagának. Itt van mindjárt Rómeó és Júlia jól ismert története, Mark Knopfler „,kiforgatásában”: „Juliet, mikor szeretkeztünk, sírva/mondtad, hogy úgy szeretsz, mint fenn a csillagok, s halálomig szeretni foglak./ Van számunkra hely, ismered a filmzenét. De mikor valóra akartad váltani,/ kiderült, ugye, hogy az időpont nem megfelelö?/Szerelmetes Romeo énekelt az utcán/ egy szerenádot. Mindenkit lehangolt a szerelmi dalával./Talált egy megfelelő utcai lámpát, és kilépve az árnyékból,/valami ilyesmit kérdezett: Te és én, mit szólsz ehhez Bébi?” A női fölénynek és a férfiúi kisszerüségnek ez a dala három évtizede ugyanazzal a frissességgel és csipetnyi iróniával szól. A zene közben az egyszemélyes előadóhoz igazodott, de a vers erejével megfejelve, a közönség új meg új évjáratait fakasztja mosolyra.

A közösségteremtő erő másik nagy forrása a póztalanság: Mark Knopfler életkortól és pozíciótól függetlenül mindenkihez szól. Nincsenek táncosságukban és rugalmasságukban kitüntetett évjáratok, nincs egymás elé helyezett nemi hovatartozás. Mindenki ugyanazon a koncerten ül, legyen fiatal vagy idősödő, legyen férfi vagy nő. És nem pattannak fel a csápolásra vagy ritmikus táncra vágyók, mindenki ugyanazt az elbeszélést hallgatja és ereszti át magán. Ez egyfajta egyenlőséget teremt mindazok között, akik elfogadják, és beülnek a hallgatóság soraiba, hogy kuncogjanak vagy elmélyülten magukba forduljanak. Ha Springsteen hallgatóságát a sokszor cirkuszias színpadkép vonzza, úgy Mark Knopflerét a cicomák nélküli egyneműség. Persze ezek sokszor ugyanazok az emberek. Akik hol a mozgalmasságra, hol a belefeledkezésre vágynak. És egyaránt tapsolnak ennek is, annak is.

Mark Knopfler alig mozog a színpadon. Szemben közönségével történeteket mesél emberekről, viszonyokról és élethelyzetekről. Magát mindegyre a narrátor szerepébe helyezi, aki csak elbeszél, de nem ítél. 
Viszont közönségének ítéletet kell formálnia: a dalok varázslata éppen ez a kettősség, a hallgatólagos felszólítás a részvételre, s ha részvételre, akkor választásra is. A legnagyobb közönségsiker a legszélsőségesebbről, a háborúról szól. Békedal ez, de egy furcsa pozícióból: nincs igazságos és igazságtalan háború, csak olyan van, amiben mindenkinek meg kell halnia. Így szól: „Ezek a köd födte hegyek/most az otthonom. De az én otthonom a lapály volt/ és mindig az is marad. Valamikor majd visszatérek a völgyeidhez és a farmjaidhoz,/ és többé nem fogsz tüzelni,/ hogy testvérek fegyverbe...Mennyi különböző világ,/ mennyi különböző nap./ Bár csak egy világunk van,/ ám mégis külön világokban élünk./ A nap most pokolra szállt, és a hold magasra kúszik. Hadd mondjunk búcsút neked,/ minden férfinak meg kell halnia./ De fel van írva a csillagfénybe és a tenyered minden vonalába,/ hogy örültek vagyunk háborúzni/ a fivérünkkel fegyverben” („Brothers in arms”).

Ezt a megrázó mondandót lassú, halk, majdnem recitativo zene kíséri, zene, ami mögül csak a belegondolás és a beleérzés léphet elő. Könnyekkel a szemekben nincsen mit mást kívánni, mint az őrültség felszámolását, a háborúskodás abbahagyását. Nem egy adott háborúról van szó, hanem minden háborúzásról és minden háború eszeveszett értelmetlenségéről. És a dal attól lesz erős és lesöpörhetetlen, hogy nem egymással szemben álló ellenségekről beszél, hanem az emberi felszámolódás mindenkit sújtó problémájáról. Egyszeriben, akár akarja, akár nem, mindenki részes lesz a bűnben és a pusztulásban. Ezt elkerülni: mindannyiunk dolga. A gyász kimondása és kollektív megélése önmagában egyesít, és segít kibontani az együvé tartozás mélyebb rétegeit. (,Brothers in arms").

Erőteljes az összefonódás, ami létrejön, de ami nem állhat meg ellenpontozás nélkül. Az ellenpontot Mark Knopfler játékos dalai jelenítik meg, amelyekben az elbeszélő remek nyarakat idéz, vagy éppen a vágyakozó kamaszt hívja elő, esetleg éppenséggel a szerelem örök tartalmairól énekel.

Ebben a játékos szellemben fogant az Emmylou Harrisszal, az amerikai country egyik legihletettebb előadójával közösen létrehozott duettlemez és a lemeznek szentelt turné életképei. Egy férfit és egy nőt látunk, akik szemlátomást félszavakból is értik egymást, s ennek állandósult öröme repíti a dalokat a feloldozó, olykor bohókás előadásmód felé. Ezek között a dalok között van áthangszerelt country és táncra hívó, gyors ütemű rock 'n' roll egyaránt, és szerepelnek duettre adaptált egyéni szólószámok éppúgy, ahogy a közös muzsikálásra teremtett, feszes ütemű darabok. A hangulatváltásnak megfelelően, ezek a dalok általában könnyedebbek, szövegük és előadásmódjuk is felszabadultabb. Jobbára a szerelemről szólnak, egymás megtalálásának öröméről és a közösen végigélt (vagy legalább: végigélhető) élményekről. „Ezek vagyunk mi a karneválon,/ ezek vagyunk mi apád autójában/ Te meg én a hiányzó kapoccsal köztünk,/ Egy kissé túl sokat ittam,/ túl hosszan voltam a napon,/ túl sokat szórakoztam/ Te és én meg a közös emlékeink,/ Ezek vagyunk mi/ ezek vagyunk mi..." („,This is us").

Ezektől a friss, fiatalkori szerelmektől többfelé vezet elágazás. A leggyakrabban a partnerek „megérnek”, és ezzel együtt kapcsolatuk is komolyra fordul komoly tartalmakkal és immár felnőtt emlékképekkel; vagy felbomlanak a gyorsan és kuszán kötött szerelmek, és az utánuk maradó űrt egyelőre az élet más vonatkozásai töltik ki. Knopfler erős kisugárzása és dalainak közösségteremtő ereje ebből a le-nem-zártságból is fakad. Úgy fogalmaz meg felnőtt felelősségeket, hogy a végső választást mindig az egyénre hagyja: ő tudja, hogy mikor énekelhető őszinte odaadással az érzelmileg erősen töltött dal („Summer of love”), és mikor helyénvalóbb az aggodalmakról és azok enyhítéséről énekelni, arról, hogy a szerelmes társ az egyetlen, aki a mindegyre előtörő aggodalmakat képes kezelni („Why worry”). Mark Knopfler arzenáljában sokféle szerelem sokféle dala található, és ez már önmagában is közösséget teremt, a választás közösségét: ki-ki választhat magának színteret, életkort és zenét. Amiben biztos lehet, az az, hogy választásáért senki nem fogja el- és megítélni. Minden daltól van 
tovább vezető út, újabb színterekre, újabb életszakaszba és a másokkal megélt közösség újabb világába. Ezek a dalok és „pozícióik” tehát igen változatosak. Nehéz elképzelni, hogy a színes közönség tagjai ne találnák itt meg a maguk problematikáját és a maguk hangját. De egyre számítaniuk kell: választani és dönteni senki sem fog helyettük. A dalok e legföbb üzenetükben egységesek: csattanós befejezés helyett a közönség mindegyre inspirációt (olykor kifejezett felszólítást) kap a választáshoz, s ha tagjai jól sáfárkodnak e hozománnyal, akkor derű és szárnyalás, amire számíthatnak. Ez a közönség más, mint Bruce Springsteené. Emez a hippivilág szubkultúráját tekintette elsődleges közegének, s kinőve a hippikorból, felnőtt életét is a legalább belsőleg megélt szembenállásra rendezte be, ahonnan csak „bölcs” benyomások és élmények hatására váltott az ellenállás nélküli beilleszkedés pályájára. Mark Knopfler közönsége a megállapodott középosztályiaké. Akiknek énekel, azok jobbára már túl vannak életük keresgélő szakaszán, elégedettek a karrierjükkel és annak ígéreteivel, továbbá túl vannak a családalapítás kezdeti fázisán is: ott vannak, ahol a maguk elvárása szerint lenniük kell, azokban a formákban élik mindennapjaikat, amik simává teszik a kapcsolattartást a szélesebb rokonsággal, de a kollegákkal és a szomszédokkal is - egyszóval, sínre került életekről van szó. Persze a megállapodottságot nem osztják ingyen, a szinten tartás figyelmet és fegyelmet követel: „Reggelente felébredve/ átnézem, hogy mit költöttem/gondoskodom ennivalóról/ és gondoskodom a lakbérfizetésröl./ Mindegyre mulatságosnak találom/ a boldogság és a pénz dolgát/s hogy az alap a pénz./ Megeshet a szerencse/ és nyersz valamennyit” ("Get lucky") - a boldogság igencsak behatárolt. A dalok nem kis része így is súrlódó: nem szólnak a beilleszkedés sikeréről, és így az önkifejezésnek csak igen körülhatárolt teret adnak. De e körülhatárolt térben elérhető némi kiegyensúlyozottság és derű, bár az önkifejezés tere meglehetősen szűk marad. Az egyén ezért folytatott küzdelmes munkája Mark Knopfler dalainak visszatérő témája („Monteleone”), megint csak a dilemmák felvázolásával, de a választástól való tartózkodással.

A megénekelt középosztályi életforma és érzésvilág nem kötődik országhatárokhoz. A megigézett helyszínek lehetnek Angliában, Olaszországban vagy éppen Amerikában: megfontolt kozmopolitizmust sugároznak. És ugyanígy: az étkezés, a fogyasztott italok, a lakókörnyezetet felvillantó lakásbelsők, az autók és motorok magukban szimbolizálják a középosztályi létforma internacionálisan elfogadott normáit, e normák határok átszelésével is értelmezhető kódjai. E hangsúlyozott kozmopolitizmus önmagában egyesítő erő, ami további magyarázatok nélkül is közösséget teremt a nagy turnék Budapesttől Barcelonán át Los Angelesig végiglátogatott városainak közönségei között. És e közönségek rendre egyenlő megszólítottakként reagálnak: a koncertek ráadásdalai arra rezonálnak, amit a középosztály a magánéleti konfliktusaiban és a szokásszerű kapcsolattartási formákban többé-kevésbé általánosan megél.

Mark Knopfler zenei és előadói erejének fontos összetevője a közönséggel folytatott párbeszéd. Ez egyrészt magukból a dalokból adódik, amelyek - láttuk - sokakat foglalkoztató témáikkal fognak egybe. Másrészt fontos a direkt kommunikáció is. Az estek zenei műsorát meg-megszakítja a párbeszéd, ami fontos élmények elbeszéléséből és zenei lenyomatuk bemutatásából szövődik egybe. Így lesz mélyen ható élmény a magányos karácsonyi autózás elmesélése, majd dalba öntése, vagy az autóstoppos utazások felidézése. Feltételezhető, hogy sokaknak volt már hasonló élménye, de azt át tudják élni azok is, akiknek életéből egy vagy más mozzanat kimaradt. Az egybefonódás alanya így az élményközösség, ami a magánéleti elemeket is a nyilvános diskurzus részévé avatja. A közönség közösséggé emelkedik, s ez teszi a zenét annak erős szövetévé. De mindezek mellett a legfőbb összetartó erő maga a zene.

A gyökerekről fentebb már említést tettem. De nem szóltam még a legfőbbről, Mark Knopfler gitárjátékáról. Mark Knopflernek a gitárhoz szinte erotikus viszonya van. Ezzel a viszonnyal közelített első gitárjához is, amellyel éjjel-nappal együtt élt, sőt aludni is magával vitte. Mára nem kevesebb, mint ötven gitárja van, s egy-egy 
koncerten legalább négyet meg is szólaltat ezekből. Összetéveszthetetlen gitárjátékának nemcsak az alkalomra gondosan kiválasztott gitárok adják a nyitját, hanem - főleg - a megszólaltatás sokrétűsége. Legsikeresebb számaiban ez a sokrétűség szinte zenekarszerűen szólal meg, és a sokféle hangzás megint összetettséget jelöl. Különböző gondolatokat mond el, és nemcsak széles skálán felvonultatott érzelmekről beszél, hanem főleg ezek harmóniájáról vagy a harmónia felé való törekvésről. És megint a zenei szövetnél vagyunk, Mark Knopfler játékának legfőbb erőforrásánál. A zenei fonatokat szétszálazni lehetetlen; legfeljebb egy fontos másik hangszer belépéséhez köthető az elválasztódás. Ez a másik hangszer gyakorta a fuvola vagy más fúvós. A gitártól teljesen elváló hangvilágával a fúvós más érzelmekre épít, hogy aztán a dal vége felé az előadó újra összefonja a szétszálazott elemeket. Ettől a bonyolult szerkezettől Mark Knopfler dalai jellegzetesen elkülönülnek másokétól - így például Bruce Springsteenétől is. Úgy érezzük - s valóban némi joggal -, hogy míg Springsteen fúvósai harsány módon emelik ki a dal szándékolt legfőbb mondandóját, Mark Knopflernél önálló és egyenrangú szereplőkként jelennek meg, mintegy a zenei kifejezés nyelvével beszélve el a verbálisan is végigmondott szöveget. De ez a zene nem aláfestés, hanem felmutatója a sokszínűen vállalható, sokfelé ágazó élmény- és érzelemvilágnak. Önálló szereplő, önálló hanggal - s a kétféle narratíva valóban kibontja a teret, melyben az átélés és a választás a hallgató dolga. Gitárjátékának ezt az összetéveszthetetlen sokrétűségét dijjazhatta a Minden Idők 100 Legjobb Gitárosa zsűrije, amikor e legmagasabb civil szakmai fórum Mark Knopflernek 2003ban a világ valaha élt legjobb gitárosainak 27. helyét adományozta.

A zene és a szöveg már említett kontrasztja és a belőle fakadó irónia további fontos építőeleme a közösségi élmény építésének. Az irónia nemcsak aláhúzza a választás egyéni jellegét, hanem távolságot teremt szándék és eredmény között, amivel elbizonytalanít ugyan, de e bizonytalanság egyszersmind kiemeli az egyéni választás jelentőségét és súlyát. A „Road to heaven” című dal jó példa erre a szerkezetre és a ráépülő szerkesztésre: édeskés, majdhogynem giccsesen szirupos zene, amivel szemben kemény szöveg áll: „Amit csak tudok, elküldöm/ a gyémántgyürüs embernek,/ aki része az égi tervnek,/ s minden bizonnyal énekelni is tud./ Most ez minden, amit megengedhetek magamnak,/ de az Úr örökkévalóságot adott nekem,/ hogy megmentsem egy szegény ország kisgyermekeit." A kontraszt a szót az ember torkára fagyasztja, és önkéntelenül további kérdésbe hajtja: ha a gyémántgyűrüs úr a minisztérium embere, hová tartozom én ebben az elrendezettségben, s vajon van-e nekem is felelősségem a szegény ország gyermekei iránt? A gyötrő kérdéstől a zene jelentése egyszerre másba fordul át: a szirupot gúnynak és iróniának érezzük. De rendre így vagyunk Mark Knopfler dalaival: a romantika, a zenei áradozás valódi, de mindig csak az érem egyik oldala. A másik az aggodalom, a félelem vagy az irtózás, s a két sík egymásra vetülése rendre előhívja az iróniát (sokszor: öniróniát) és az alapvető megkérdőjeleződést. Így a dalok intellektuális élményt is adnak, és egyre szélesebb értelmiségi érdeklődés tárgyává teszik Mark Knopfler alkotásait.

Ehhez társul még a politika. Szemben Bruce Springsteennel, de Cseh Tamással is, Mark Knopfler közvetlen részvétellel nem politizál, állásfoglalásai azonban kőkemény politikai mondandóról tanúskodnak a dalokban. Láttuk már fellépését a háború ellen, de a társadalmi egyenlőtlenségekkel szemben is: a dalok körbejárnak egy ügyet, s e körbejárás révén közvetítik a politikai mondandót. Van itt szó a nők egyenlőtlen státuszáról, a fiatal generáció elveszejtettségéről, a férfias kiszorítós versenyről és az álomszerű kimenekülésről - de ezek a mondandók nem egykönnyen adják magukat. Egy-egy dal többszöri meghallgatása szükséges ahhoz, hogy a látszólag lágy szavak mögül kibányásszuk a kemény politikai mondanivalót. Mindez teljes összhangban van a dalok előbbiekben bemutatott építkezésével és azzal, hogy még a legkeményebb témák esetén is az alkotó véleményeválasztása egy a lehetségesek közül. Éppen a politika talán az a nehéz terep, ahol Mark Knopfler legfőbb válasza az egyéni döntés szabadsága és felelőssége - és ennek politikája. Márpedig ezt a politikát, a diskurzus szabadságát 
és felelősségét semmilyen módon sem áldozná be, még akkor sem, ha esetleg szép és vonzó volna az egyének unisono választása. Így viszont maradnak a lekerekítetlenségek és marad a bizonytalanság, amely azonban új, gazdag elemeket szívott magába, remélhető tehát, hogy termékeny dialógusnak nyit lehetőséget.

A dalokhoz hozzátartoznak a klipek, amelyeket sokszor maga Mark Knopfler rendez meg, de akár o,, akár nem, mindig nagyon igényesek. A klipek egy része a zenei stúdióban készült, mégpedig azzal a céllal, hogy bevezesse a nézőt a lemezkészítés világába, megmutassa azokat a technikai eszközöket, amelyek értő múködésbe hozatala révén lesz a felvett nyersanyagból kifinomult hangzású dal. Mark Knopfler pályájának kezdetén kitanulta a produceri munka csínját-bínját, és ma lemezeinek többnyire ő a producere. Így közvetlen hatást gyakorol a hangzásvilágra, az éneken túl egy-egy hangszer előtérbe állítására vagy a hangszerek közti harmonikus illeszkedés megvalósítására. Mi pedig látjuk a mestermunka technikai bázisát és a szerepmegosztást, aminek révén e technika célszerű múködtetésével a vegytiszta hangzású lemez előáll.

A „konyhatitkok” kisfilmekre épülő kibeszélése azonban a dalokhoz kapcsolódó képi világnak csak az egyik része. Rafináltabbak azok a kisfilmek, amelyek mintegy a produkció harmadik lábaként egy-egy kerek történetet mesélnek el. És a történet nemcsak illusztráció - sokkal inkább egy e vonatkozásban ki nem merített további múvészeti tevékenység lenyomata.

Az egyik ilyen történet, a „Poor boy blues” című régi dal feldolgozásához készült kis filmecske jól mutatja, hogy mirôl is van szó. A dal a szegénység miatt beteljesíthetetlen szerelemről szól, amiben egyszer csak eljön a remélt fordulat, az akadályok elhárulnak, és a két szerelmes egymásra találhat. A történet azonban az egyszerű kis szövegecske fölé emelkedik az előadásmóddal. Furcsa emberek házában vagyunk, ahol erősen tikkelők, extrán magasra nyúlt lányok és súlyos sebesültek élnek együtt, és gondozónők gondoskodnak ellátásuk minden részéről. Ebbe a közegbe robban be a gyors rock ' $n$ ' rollal előadott dal úgy, hogy egyszeriben mindenkinek táncolni támad kedve. A két zenész - Knopfler és Atkins - csak figyelik a szemük előtt kibontakozó szerelmi jelenetet: egy fiatal fiú vágyakozását a nála három fejjel magasabb fiatal gondozónő iránt, s a kapcsolat itt, a szemünk láttára össze is jön. Mintha ő "csinálta” volna, Knopfler végigneveti az egész dalt, s ott szurkol a maga csendesebb módján Atkins is. Jókedvük átragad a ház lakóira is, a maguk módján a gondozónők is táncra perdülnek - mindenki örül a beteljesült szerelemnek. Ám ott van mögötte még egy igazság: ha a fizikai térben nem is, az emberközi viszonyokban ápolni lehet a teljes nyitottságot és az egyenrangúságot, amit a dal közepén Knopfler még ki is emel és emberi mivoltában a pozíciótól független eseménnyé avat a maga „tikkelős” vállhúzogatásával. Az embernek valahogy az jut eszébe: így, ezeken az alapokon lehetne az igazán jó szociális munkát felépíteni, és még akár jó szándékú leereszkedés helyett kliens és szolgáltató egyenlő emberi viszonyát megvalósítani benne („Poor boy blues”).

Vagy vehetjük a „Wherever I go” címú dalt, a szerelmétől való elválást elbírni nem tudó fiatalember énekét. Maga a dal - a zene és a szöveg - finoman láttatja a kibírhatatlan fájdalmat, a vágyakozást, hogy az idegekben és a gondolatokban kiiktathatatlan mélységgel jelen lévő szerelmes valóban jelen legyen, maga legyen az álom beteljesülése és ne az álom hiábavaló kergetése. A filmen ennél többet látunk. Látjuk, ahogy a szenvedő fiatalember csapot-papot hátrahagyva elhagyja a lakását, és nagy léptekkel kimegy a tengerpartra. Látjuk, nemcsak az álmatlanság elől menekül: indul a beláthatatlan tenger felé. Előbb csak a kabátját hagyja hátra, szépen hajtogatva, afféle jelnek, ha a kedves a keresésére indulna. Később a zakóját, már semmit se bánva, ledobja magáról, s mintegy futva megy előre - mi már tudjuk, ha a dal nem mondja is, hogy fut, fut magába az öngyilkosságba. A képi megjelenítés tehát - akárcsak az előbbi vidám dalnál - hozzátesz a zenei ábrázoláshoz, és azt nagy súlyokkal mélyíti („Wherever I go”). 
Vagy vehetünk egy harmadik példát, a finom iróniával megénekelt szerelemről a „Long cool girl” című dalban. A dal két főszereplője egy magas, vékony lány, aki egy kirándulás alkalmával teljesen összesározott biciklijét hozza a kerékpárjavító múhelybe megtisztításra. A tisztítást végző fiú egycsapásra beleszeret a lányba, és munka után megkeresi. Flört szövődik a két fiatal között, mígnem egy szép napon a fiú felfedezi az átverést, azt, hogy a lány hiába „magas, klassz csaj, akinek nevét szeretem kimondani” valójában „egy kartáncosnő bőrébe bújt némber”, párhuzamos kapcsolatokkal („Long cool girl”).

Mark Knopfler legutóbbi alkotásai e hármas felé építkeznek. Vagy koncertfelvételek, ahol a zene és a szöveg mellett a harmadik sík a zene találkozása a közönséggel és a köztük lévő diskurzus, vagy az előbb idézettekhez hasonlóan megépített, a történetet tovább mondó képi megjelenítések, amelyek érzékileg is a legnagyobb hatást teszik a maguk háromszoros vetületében, a dallam, a szöveg és a képvilág elkülönülő, de összeérő ábrázolásmódjaival. Ezek a klipek kifelé szólnak: a szabványos, egysíkú, a számot csak kiszínező képanyagok illusztratív, ám tudatosan egysíkú popábrázolásai helyett a párbeszéd felé húznak, s helyet kérnek maguknak a film világában is. A kisfilmek Mark Knopfler rendezői tehetségéről tanúskodnak. Ő maga inkább kalandnak, kirándulásnak tekinti a megmártózást egy másik múvészeti ágban. S bár a mondandó igazáért nyíltan kiáll mint saját gondolatai és attitűdje hű lenyomatáért, ezt nem kitüntetetten a filmre, hanem a mű hármas egységére vonatkoztatja. Igen komolyan veszi tehát a klipeket, és felelősséget érez azok iránt is, amelyek nem közvetlenül az ő keze alól kerültek forgalomba. A dalok védelmének egyik formája, hogy szisztematikusan odailleszt minden egyes szám filmbéli bemutatása mellé egy másikat, a lecsupaszított zenei anyagot. És ez folyamatosan ismétlődő próbatétel. Ha a dal klipváltozata más képeket vonz, mint maga a szerzői mondandó, akkor Knopfler könyörtelenül bánik el vele: egészen új klipet kell csinálni, függetlenül a dal korától - a régi számokhoz éppúgy, mint fiatalabb társaikhoz. Egyik estéje során, a közönséggel beszélgetve, meg is fogalmazza a maga credoját a tárgyban: „Szeretem a régi számokat játszani. És nem engedek semmiféle cinizmusnak. Ezek a dalok fontosak az embereknek, mérföldkövei az életüknek, és nekem tisztában kell lennem ezzel. Ezért nem engedem el őket" (interjú a BBC számára - 2013).

De a megjelenítésben azért vannak változások. Ottérződik a felhalmozott élettapasztalat, és az, hogy az idő múltával átrendeződnek a fontossági sorrendek: ha évtizedekkel ezelőtt egy szám a magány fájdalmáról beszélt, akkor mai párja a magányosság rezignált tudomásul vételéről; ha hajdan az állandó aggodalmaskodásról volt szó, úgy a dal mai megszólalásában az igazán fontos a partner, aki támaszt és békét nyújt, és részben átveszi az aggodalom fájdalmát. Ez az élettapasztalat mentén való áthangolódás évtizedeken át partnerségben tartja Mark Knopflert és a közönségét. Ha Bruce Springsteen közösségteremtő ereje örök fiatalságában és játékosságában rejtőzik, úgy Mark Knopfleré abban, ahogy együtt gondolkodik és lélegzik a maga korosztályával, és ehhez a korosztályhoz mint törzshöz kapcsolja az intimitás újabb rétegeit - mint láttuk, a tartalmak fontossági rendjének életkorilag és az életpálya változásaival lépést tartó átrendezésével. Azon túl, hogy maga az efféle rugalmasság relativizálja és relativizáltságukban egyenlővé formálja a korosztályi kötődésű dallamokat és szövegeket, a dalok az igazságok viszonylagosságát hirdetik. Ez a belátás kitágítja a bevonódás, a feloldódás határait, és maga lesz a knopfleri muzsikálás közösségteremtő erejének legfőbb bázisa. Knopfler tehát mindezzel egy értelmiségi programot valósít meg. A program lényege abban áll, hogy magunk vagyunk a saját demokráciánk alakítói. Ha a türelmen és bizalmon alapuló attitűdünket ki tudjuk terjeszteni éppúgy a magánélet terére és viszonyaira, mint társadalmi, politikai részvételünk egyéb relációira, akkor e sokféle, de egyirányba mutató egyéni magatartás maga lesz az erő, amiből a demokrácia és annak intézményrendszere építkezik.

Az, hogy ez a magatartás értelmiségi program volna, sehol nem mondatik ki. De a programmal való azonosuláshoz feltételek is kellenek. A program feltételezi a kifejezés szabad megválasztását és e gesztus 
retorziók nélküli, szabad kiteljesítését. Márpedig ezekkel a feltételekkel csak a közép- és felsőosztályok rendelkeznek - így csatlakozás és beolvadás is tőlük várható. Mindeközben Knopfler a társadalmat tagoló merev választóvonalak felismerését tekinti az értelmiség és általában a középosztály legfőbb kollektív dolgának, és e felismerés alapján várja a korlátok merevségének oldását, majd teljes eltávolításukat. Mindez, mint láttuk, sokrétű feladat mind az egyén, mind a közösség számára. De Knopfler a korlátok lebontását teszi a sok feladat között is legfontosabbként az élre. Ezzel meghatározza saját helyét: egész életmúve a baloldalra, pontosabban a baloldali liberálisokhoz húzza. Ugyanakkor programként e beállítódás sehol nincsen kimondva: a dalok egyénekről, egyének választásairól és e választások közelebbi bemutatásáról szólnak. Mint egy-egy ballada, homályban hagyják a „megcsinálás” pontos történetét: nem tudjuk, hogy mitől változik meg a szegény fiú élete, csak a végeredmény, maga a változás ténye a fontos; nem tudjuk, hogy a bulizó ifjúságból hogyan vezet út a felnőtt életbe és a karrierbe, de alanyunkat egyszer csak új szerepében látjuk; nem tudjuk, hogy hogyan zajlanak egy szerelmes élet hétköznapjai, de tudjuk, hogy a szerelem önmagában nem old meg válságot és nem csökkent szenvedést stb. Ezek a dalok - bármilyen különböző történeteket mesélnek is el - közös séma körül szerveződnek: az egyén áll szemben az arc nélküli közösséggel, s neki magának kell megtalálnia a saját útját e közösséghez. A választás minden segítség mellett is egyéni marad, és végső tartalmában az erkölcsi felelősség az előbbiekben már vázolt fő centruma körül tematizálódik.

Azzal, hogy a közösségiségben rejlő erkölcsi dilemmákat emeli a középpontba, Knopfler azt sugallja: ha elbeszélni az értelmiség beszéli is el e dilemmákat, maguk a dilemmák nem réteg-, hanem korszakspecifikusak. A korszak a fogyasztás motorjára és dinamikájára mozgó posztindusztriális társadalom kora, ahol a többségi normák kőkeményen meghatározzák és behatárolják az egyén mozgásterét. És ez az egyén nem egy-egy réteg reprezentánsa, hanem maga az általánosság megtestesítője. Az általánosítás eme igen magas szintjén nehéz lenne Knopflerrel vitába szállni. Nem is igen kerül sor klasszikus értelemben vett vitákra, a mély hatás a „lábbal szavazás" közönségi gesztusaiból világlik ki. A nagy közönségsiker egyúttal bizonyíték amellett, hogy releváns és őszinte hangon nemcsak az értelmiségi rétegekkel, de a szélesen értelmezett középosztály tagjaival is lehet szót érteni. A hitelességet márpedig a közös tapasztalat szavatolja, amely végső hatásában akár fontosabb összetevője lehet a dalnak, mint maga a verbálisan megformált dalszöveg. A hitelesség emel egymás mellé igen különböző technikai színvonalon készült felvételeket - különösen a koncertfelvételeket. Érdekes megfigyelni, hogy a különböző országok és városok közönsége mennyiben hasonlít egymásra, illetve, melyek a legfontosabb különbségek. Azt látjuk, hogy ez utóbbiak részben megcélzott programjuk szerint, részben dinamikájukban különböznek. A budapesti közönség inkább a balladisztikus, ritmusukban is lassúbb számokra volt vevő, míg például a barcelonai vagy sevillai közönséget leginkább az európai tradícióhoz való tartozásról szóló számok érdekelték. Az utóbbi koncertek középpontjában a nyugati örökség felmagasztalása és az „idők romlása”, a szebb napokra és jobb erkölcsökre való visszaemlékezés áll („Once upon a time in the West”). És az előadó megerősíti ezt az odatartozást, amely féltett, de egyszersmind kiiktathatatlan része a dél-európai identitásnak. Már a megerősítés gesztusáért is forró hála dukál, de azzal, hogy ez lett a koncert középpontja, megsokszorozódott a hatás, és e nyilvánvaló, mégis meglepő fejlemény megünneplése szintén nem maradt el. A dal egyúttal példája annak is, ahogyan Mark Knopfler a politizálást érti. Állásfoglalásai mindenkor a közélet viszonyaira és feszültségeire vonatkoznak: a nyugati normák kiürülésére, az emberek közötti előzékenység eltűnésére, a kiveszőben lévő figyelmes udvariasságra, az ember mint ember értékének alászállására. És a megfigyelt jelenségek, viszonyok és feszültségek mögött mindig ott a kérdés: kié a felelősség, és ki tudna tenni a dolgok jobbra fordulása érdekében. Nem kapunk egyértelmű választ, de valószínúleg ilyen nem is adható. A feszültség ott marad a levegőben. Ha Springsteen lefordítja a politikai teendőt konkrét aktorokra, Mark Knopfler beállítódását éppen az efféle egyértelmú lefordíthatóság elhárítása jellemzi. Az világos, hogy 
mindannyian érintettek vagyunk, de az már kevésbé, hogy érintettségünkkel mit is kezdhetünk. Mark Knopfler saját választása egyértelmű: gyönyörű zenéket szerezni okos szövegekkel, és megpróbálni eljuttatni ezeket a legszélesebb közönséghez - a film segítségével vagy anélkül.

Valóban: kevesen vannak, akik olyan körültekintéssel igyekeznének biztosítani a demokratikus hozzáférést, mint ezt Mark Knopfler teszi. Amint a számok vagy az albumok elkészülnek, a lehető legrövidebb időn belül ott találjuk azokat a YouTube-on, igyekezvén megtartani a hangmérnöki munka magas színvonalát a hangzásban, a képi anyagban. Így nem is csoda, hogy Mark Knopfler hatalmas rajongói tábort tudhat magáénak. Az élen még ma is ott vannak a régi Dire Straits-számok, és ott vannak persze a szólókarrier produktumai mind igen magas nézettségi számmal. És Mark Knopfler karban is tartja széles kapcsolatrendszerét. Külön irodát tart fenn legközelebbi munkatársa, Guy Fletcher vezetésével, hogy a bejövő e-mailek meg legyenek válaszolva, és ha lehet, a hívek kedvezményes jegyet kaphassanak a soron lévő koncertekre. Pedig látszatra Knopfler nem egy mosolygós személyiség. De a látszat csal: közönségével igen barátságosan kommunikál. De talán ennél is fontosabb és megvilágító erejü, hogy a mindig komoly arccal előadó Knopfler igazán akkor mosolyog, amikor zenésztársainak valamelyike külön szép teljesítményt nyújt. Láthatjuk az őszinte derút és az elismerést az arcon: egy adott számban a fuvolaszólót többre értékeli, mint saját közremúködését, pontosabban, mosolya és széles karral mutató-ölelő gesztusa annak szól, hogy a gyönyörű fuvolajáték nélkül a nagysikerű előadás meg sem születhetett volna („Get lucky”). Máskor azzal, hogy a szám vége előtt leveszi a nyakából a gitárt, hangsúlyt ad a számot záró zongorajátéknak - megint csak mosollyal és a jól ismert, szélesre tárt karmozdulattal emelve ki azt („Our shangri-la”). Mark Knopfler kedvessége és előzékenysége mindenekelőtt a partnereinek szól. Bemutatásuk egy-egy koncerten mindig egyéni és megismételhetetlen. A társakról van egy-egy története, aminek persze hangszertudásuk áll a középpontjában, de időnként előkerül egy jókedvűen közösen elköltött vacsora vagy egy pub-beli sörözés mozzanata. Gitározni mindenki tud, „ebből élünk", mondja, de emellett mindenki több hangszeren játszik, s ha például dobon, úgy az is másolhatatlan. A viszonyok szemlátomást igen bensőségesek és megállapodottak, olyannyira, hogy mikor egy egész lemezt és a hozzá kapcsolódó turnét Emylou Harrisszal, női partnerével prezentálja, a közönségből többen intim magánéleti viszonyra gyanakodnak a pár harmóniája láttán. Pedig a magánéleti harmónia terepe szigorúan a család, Mark Knopfler harmadik felesége, az írónő-színésznő Kathy Aldridge, két lányának anyja, és az előző házasságból született ikerfiúk - ők azok, akikkel az igazán bensőséges ünnepeket - így hetvenedik születésnapját is - megüli, és ők a legfontosabb hobbi, a velük töltött időnek kiemelt hangsúlya van. Mellettük igen fontosak a barátok; a közös zenélés feltűnő összetartást fejez ki, ami nemcsak a munkát jellemzi, de a társakkal való barátságot is. Mark Knopfler mély és tartós kapcsolatokat ápol, aminek a fizikai közelség nem mindenek előtt való előfeltétele. Így például távoli barát Bob Dylan vagy Eric Clapton, akikkel ritkán adatik az együtt zenélés lehetősége, de ha igen, annak a hátterében ott van a mély vonzalom és a feltétlen tisztelet, amivel a partner munkájának és teljesítményének adózik. Ugyanilyen elmélyült pillanat lesz, amikor kamaszkora nagy idoljával, Henk Marvinnal játszik együtt. A színre lépésből látjuk, hogy korábban személyesen nemigen találkozhattak, persze nyilván tudtak egymásról. Mégis, az első hangtól kezdve a közös gitárjáték olyan harmóniát hoz elénk, aminek megélésére és prezentálására csak egymást mélyen ismerő emberek szoktak képesek lenni. A szám - Mark Knopfler nagysikerű instrumentális dala, a „Going home” című - persze alkalmas is az elmélyült összefüzöttség felmutatására. Egy olyan dalról van szó, amely hangzásvilágában közel áll a Shadows-együttes egykori vezetőjéhez is. Mi meg csak ámulunk az összeérleltség láttán-hallatán, ami ha magában lenne is, kisugárzásával mindenképp hatalmas közösségteremtő hatóerejére, Mark Knopfler e rendkívüli adottságára irányítaná a figyelmünket („Going home”). 
Mert Mark Knopfler külön világokat egymás közelébe hozó személyiség - ez vitán felül áll. És közösségteremtő a zene, amit kapunk tőle. Ez az erő azonban nem egykönnyen hagyja magát felfejteni. Első pillantásra csak azt érzékeljük, hogy ez a zene kortalan abban az értelemben, hogy korosztályi metszetben mindenkihez szól. Bár a megénekelt élettapasztalat kötődhet az ifjúsághoz vagy a megállapodott felnőttkorhoz, a befogadás felől nézve eltúnnek a különbségek. A zenei rétegek felülemelkednek rajtuk és egybefogják azokat. Ugyanígy eltúnnek a két nem közötti különbségek. Legyen a dal témája akár egy férfi szerelmi bánata, szöveg és zene szövetsége felemeli azt, és nemi hovatartozástól függetlenül, a kapcsolatok mélyen beivódó és sorsot meghatározó jelentőségéről szól. De hasonló módon, Mark Knopfler dalai egybe emelik a különböző társadalmi osztályok széttartó tapasztalatait. A zene a legáltalánosabb értelemben középosztályi zene: a szöveg utalásai ezt rendre nyilvánvalóvá teszik. Olyan földrajzi és szellemi-kulturális helyekről szólnak, amelyek éppen a középosztálynak szokásszerűen használt terei - akár fizikai értelemben, akár a megmozgatott szókincs vonatkozásában. Középosztályiságában azonban ez a zene nem kirekesztő, hanem befogadó. Egybeötvözi a középosztály rétegeit, a gürcölő kistulajdonostól a minisztériumi tisztviselőig, s azt emeli ki, ami életvilágukban közös. És általában: Mark Knopfler zenéje közösségi zene, az egyént mindig beágyazottságában láttatja. A közösséghez azonban politikai erőt nem rendel: az egyén szabad választásának hagyja meg a politikába beleszólni kívánó csoporthoz tartozást vagy éppen a csendesebb, visszahúzódóbb, meditatív pozíció elfoglalását. S miután a választást mélyen tiszteli és a szabadság legfőbb megnyilvánulási lehetőségének tekinti, ettől zenéje mélyen demokratikus, és éppen e demokratikus voltában rejlik összetartó erejének lényege. Mert a szabadság mint legfőbb érték valóban nem ismer korlátokat: az mindenkit megillet, korától, nemétől, társadalmi állásától és nemzeti hovatartozásától függetlenül. Ez persze csak normatíve igaz: a csoporthovatartozás erősítő vagy gyengítő körülményeivel a társadalom keresztbe-kasul szántja a szabad választás egyének közötti egyenlőségét. És ezeknek az erőknek a bemutatását Knopfler ugyancsak dolgának tekinti. Így lesz dalbéli szimpátiájának tárgya az otthonról menekülő, függetlensége megteremtésére még kockázatos utcai kalandok árán is törekvő egyetemista fiú, vagy az emlékekkel összetartott egykori szerelem öregkori visszfénye, vagy a háborút elutasító, bátor ifjak fellázadása, és maga a mindenen átsütő hazavágyás egy talán nem is létező, befogadó és derűs otthonba.

Más dalokban a szerelem lesz az egybetartó erő, a szerelem, amelynek fázisait érzékeljük, de a keret elmosódó: a dal szólhat egy diákszerelem lassú kihűléséről éppen úgy, mint egy együtt élő pár szomorúságáról egy közösen leélt élet mulandósága láttán. Az „Are we in trouble now” című dalt éppen a helyzeti fókusza teszi különlegessé, ami miatt az életkor szerinti különbségek háttérbe szorulnak, és a dal végül általánosan szól a veszteségekről és a veszteség felkavarta érzelmekről. „Nem éppen a zene,/ nem éppen a bor tette,/ valami másfajta varázslat adott hírt magáról a gerincemben,/ aztán tévelygésemben rád ragasztottam magam,/ drága, hogyan történhetett ez,/ most mindenesetre bajban vagyunk." Bár a dalban a férfi viszi a prímet, és az ő érzelmeiről kapunk elsődleges híradást, a további strófákban egyenrangú átélhetőséggel megjelenik a kudarcba fúló kapcsolat feletti női bánat is - pontosabban, egy ponton túl másodlagossá válik a szerep, és a hangsúly magára a veszteségre, a mulandóságra kerül. Ez a kétfelőli érzelmi azonosulási képesség talán az egyik legfontosabb tényezője az összekovácsolásnak. Mark Knopfler úgy beszél különnemű hallgatóinak érzelmeiről, hogy nem állít fel sorrendet közöttük. A nemek közötti közösséget a lefelé csúszó pályára került szerelem és az efeletti bánat teremti meg. Ugyan az érzelmek nem felcserélhetőek, de ebben az egyenrangúságban egyforma fontossággal jelennek meg, és ezért ritka erővel kapcsolják egybe a szereplőket. Más szerelmi dalokban a közös emlékek és azok tudatos ápolása jeleníti meg az összetartó erőt. Megint előbb a férfivilág felől lépünk be, de a dal kitágítja a keretet a közös-ség felé, amiben a férfi és a nő egyként osztozik („True love will never fade"). A magasba repülő körhinta az emlékek húzóképe, s nemcsak ebben a dalban. Megtestesíti a repülést, 
a szabadságot és a játékosságot - mindezt ismét a képek világában mondja el, pontosabban, teszi hozzá a kölcsönös szerelem felemelő érzéséhez.

Persze nemcsak a magánéleti dalok teremtenek összetartozást. Ott vannak a történelem nagy nevei és figurái, ott vannak a patrióta büszkeség megtestesítői. Mark Knopfler bőséggel megemlékezik róluk, de nem éppen nagyságukról, hanem hétköznapi emberi vonásaikról beszél. Így lesz Bonapartéból trónfosztott vezér, aki felel a dicső francia sereg szétzülléséért, és aki helyett már csak az Úrhoz lehet imádkozni: „Mióta Moszkva lángokban, eszméletlenül megfizettünk,/ amint a szláv seregek darabokra tépnek bennünket,/ halottjaink szétszórva a világban, pedig a halál könnyü megváltást hozhatna,/és a Grand Armée rongyokban,/mint fagyott, éhezö koldusok hada,/ mint patkányok lopkodnak egymástól/ és verekednek ki-ki a másikával.//Uram, mentsd meg a lelkemet a gonosztól,/ és gyógyítsd meg a katonák szivét,/ elvesztettem a bizalmamat, hogy megtartasz engem, Uram,/végeztem Bonapartéval” („Done with Bonaparte”). Egy ilyen dal tradicionális ellenségeket hoz össze egy közös fohászban: a franciák nem kevésbé várják az értelmetlen háború végét, mint a hol megvert, hol győztes oroszok. A züllés, az értékvesztés általános és nincs rá felmentés, mert a háború nem dicsőséget hoz, hanem csak fájdalmat és szétesést. És éppen ez, a megúszhatatlan pusztulás lesz e dal és történelmi párjainak fő közösségteremtő mondandója, keresztül népeken és országokon, de történelmi korokon is - ahogy azt a „Brothers in arms” című dal esetében láttuk. Ezek a dalok zeneileg szúkebb sávot fognak be, mint az érzelmekről, a szerelem hozta örömökről és bánatokról szólók. A „Done with Bonaparte” pergős, kissé a hadszíntéri vágtázásra emlékeztető gyors, ismétlődő sorokban beszéli el a Bonaparte iránti bizalom elvesztésének történetét. Ami kiszól, kikiabál a zenéből, az a refrén: „végeztem Bonapartéval”. És végül már csaknem a közönség is énekli a visszatérő sort - ennyire nincs más út, mint a hadvezér trónfosztása és kiátkozása - a vezéré, aki szép és gazdag földeket, dús termést ígért, de amit esztelen háborúja hozott, az csak a csonkítás, a halál, és az élők erkölcsi földre zuhanása. És ebben a helyzetben már nincs győztes és vesztes, csak a szétzúzódás és a lealacsonyító káosz marad. Ez pedig egy új erkölcs felépítésére a kisembereket fogja össze, függetlenül attól, hogy a harcok kezdetén melyik náció melyik zászlaja alatt vonultak csatába. A közös erkölcs és emberi értékrend kívánása tehát ezeknek a daloknak a legfőbb közös üzenete - valóban helytől és nemzeti hovatartozástól függetlenül, de egy új, nagy, közös cél érdekében. Ez a nagy, közös cél pedig az újra elővarázsolt humanizmus, amely a szerelem és barátság magánéleti viszonyainak éppúgy a táptalaja, ahogy a közösség intézményei számára is az. Itt azután a knopfleri dalok két világa összeér: megpillantjuk, hogy ezek nem is külön világok, hanem ugyanannak az egy, közös világnak megmutatkozó más-más arcai. És kötőszövetük is egy: a humanista erkölcs, amely az egyén szabadságán és választásain nyugszik, s amely erkölcs fölé nem emelhető semmilyen instancia anélkül, hogy éppen ezt a legfontosabb tartalmat meg ne karcolná, rosszabb esetben fel ne koncolná. A szabadság és a választás márpedig elidegeníthetetlen az egyéntől, és minden egyénnek egyformán jár. A társadalmak kvalitása - demokratikus jellegük - azon méretik, hogy ezt a mindenkinek kijáró szabadságot mennyire tekintik szentségnek, és hol, mivel rombolják. A háború a legnagyobb és legdrasztikusabb rombolás - Mark Knopfler világképében a legfőbb ellenség. És éppen azért az, mert az egyén szabadságának és választásának helyébe egy magasabb rendűnek mondott kényszert ültet, amihez lázadás nélkül alkalmazkodni mindenkinek kötelessége. A negáció kimondása Mark Knopfler egybetartó mondandójának másik tartópillére - éppen a görbe tükör tagadásának tagadása, azé a torzképé, amely a humanizmust elröppenő, gyenge kötőanyagnak mutatja. E görbe tükörkép ellen lázadni: innen veszi kezdetét a harc a humanizmus visszahódításáért és a demokratikus elvek és gyakorlatok megerősítéséért. Mark Knopfler különösebb látványos zászlóbontás nélkül magát e harc elkötelezettjének és zenei hírvivőjének tekinti 


\section{A KÖZÖSSÉGTEREMTÉS SÍKJAI}

A három zeneszerző-előadó bemutatása néhány érdekes tanulsággal szolgál. A legfőbb tanulság: bár a közösségteremtés és az egymástól társadalmilag távoli közösségek egybekapcsolása rokonítja őket, a megvalósítás útjai igen különbözőek. Várakozásainkkal ellentétben, a közösen végigélt korszak hatásainak kontúrja eléggé elmosódott. A generációs egybetartozás leginkább a zenei tradícióban mutatja meg magát. Bár igen-igen különböző zenei fogásokkal és a zene különböző bonyolultságával operálnak, mindhárom előadó a rock'n'roll, a jazz és a country-, illetve népzenei motívumok kombinálásából építkezik. Ez nem is csoda: a jazz a hetvenes-nyolcvanas évek könnyűzenei alapnyelve, ami alól nem vonhatják ki magukat. A hagyomány elsősorban a számok ritmusvilágában és az improvizációs elemek hangsúlyozásában jut kifejezésre. A számok egy jó részére táncolni is lehet - ami különösen a korszakban megkerülhetetlen rockos hatásoknak köszönhető. A zenei alapok közös mivoltán túl, a hagyománnyal különbözőképpen bánnak. A tágabb jazzes vonatkoztatás Cseh Tamás „dúdolós” dalaiban inkább aláfestés; Bruce Springsteen balladáiban a bluesos kötődés, míg Knopflernél a country és a jazz összefúzése játszik döntő szerepet. De e hangsúlykülönbségek ellenére, a zenei tartalmat tekintve a három előadó dalai felelgetős viszonyban állnak egymással. Bizonyos értelemben egy bokorból valók.

Túl a zenei alapok rokonságán, a megénekelt témákban a generációs egybetartozásnak azonban kevés nyomát látjuk. Hiába a közös történelmi kor, a hetvenes-nyolcvanas évek hármójuk számára három problematikát ajánl. Cseh Tamás a közös nemzeti emlékezet és az élményekben közös fiatal évek bázisán a nemzeti egyesítés lehetőségeit keresi. Dalainak kerete a nemzeti közösség törékenysége, aminek okait az egybefúző történelmi referenciák hiányában és a korokon átívelő kiszolgáltatottságban látja. Bruce Springsteen a hippi életforma marginalizálódásában és a munkásrétegek kiszorítottságában jelöli meg a közös alapot, amin az „amerikai álom” beválthatósága helyett az elnyomással szembeni széles társadalmi fellépés nyugodhat, és magát e történelmi küldetés szószólójának tekinti. Mark Knopfler számára a kisember vágyai és küzdelmei szolgáltatják a tematikus alapot, amelynek háttere előtt a középosztályi normává lett értékek internacionalizálása a generációkon átívelő közös cselekvés által kitöltött tér és keret.

Még a mindhármuk által megénekelt szerelem is más és más fénytörésben mutatkozik. Cseh Tamás Ács Marija vagy Horváth Annája megbicsaklott női sorsokat és a szerelmesek eltávolodását mutatja. Nem véletlenül, ezek a lányok külföldön próbáltak szerencsét, de az új világokba való beilleszkedés igencsak korlátozott sikerrel járt számukra. A régi szerelemhez való visszatérés közös alapja a frusztráció, ami a földrajzi keretek különbözősége ellenére a bármily megtépázott együvé tartozás közös kötőszövete. Bruce Springsteen női figurái a hippi életformával, szüleikkel és a beilleszkedés imperatívuszával szembefordult lányok, akik a párkapcsolattól legfeljebb kikapcsolódást remélnek, de támaszra hiába várnak. Férfiakat és nőket leginkább a közös időtöltés és szórakozás köt egybe: mélyebb együvé tartozásuk nyomaival nem találkozunk, legfeljebb egymás megtalálásának nehézségei és komplikációi kerülnek elő. Mark Knopfler asszonyai párjuknak partnerei ugyan, de közösségük kizárólag a magánszférára szúkül. Az asszonyok sokszor férfipárjaiknál szabadabbak és szókimondóbbak. De önálló törekvéseket, felemelkedési és kitörési vágyakat csak a férfiaknál látunk - igaz, ott is kétkedés és irónia kíséretében. Az üzenet a magánélet erőforrásainak szúkös volta; mégis, egyedül ezeknek az erőforrásoknak a mozgósítása adhat védelmet a mindennapi élet kihívásaival szemben.

A három szerző dalaiban megidézett történelmi emlékezet toposzai sem tanúskodnak közeledésról. Cseh Tamás a nemzeti múlt figurái felé fordul, és dalaiban a közös emlékezet a vasfüggönynél még régiós kiterjesztésében is mereven zár; Bruce Springsteen számára az egybekovácsoló történelmi élmény a vietnami háború - de mintha annak elutasítása csak az amerikai társadalom problémája volna; Mark Knopfler 
ábrázolásában a történelmi hőstettek figurái mára kiürült papírmasévá váltak - nemzeti keretük éppen annyira érvénytelen, mint általános kiterjesztettségük.

A széttartó témák közepette egyetlen közös generációs magként a háború elutasítása marad, de az is háromféle érvrendszer alapján. Cseh Tamás a megalázottságot és a kisemberek végső tehetetlenségét énekli meg; Bruce Springsteen a kiszolgáltatottságról és a háborús terhek és veszélyek feketék és fehérek, középosztályiak és munkások közötti szélsőségesen egyenlőtlen elosztásáról beszél; Mark Knopfler szemében a háború a humánum elleni gyilkos támadás, amiben nincs „igazságos” vagy „igazságtalan” részvétel - az elembertelenítő hatás általános. Mindazonáltal a háború következményeit hasonlóan látják. Legyen szó akár a vietnami háborúról, akár a második világháború emberi csonkoltságokban és sorsok megbicsaklásában ma is velünk élő következményeiről, akár fegyverfogásba torkolló lokális feszültségekről, a fizikai és lelki megnyomorodáson túl, mindhárman az erkölcsi lealacsonyodásra helyezik a hangsúlyt, amivel a pacifista mondandót elsődlegesen morális keretbe foglalják.

A fentiek után nem meglepő, hogy az élettörténet szerepe és zenei kifejezésmódja is lényegesen különbözik a három szerzőnél. Cseh Tamás dalaiban a diákévek vagy a városba való felköltözés élményei áttételek nélkül, közvetlenül szerepelnek. Összhangban a közönségével együvé tartozó előadót megjelenítő színpadi fellépéssel, az élettörténet darabkái a közös sorsot és az azon alapuló közös-séget hivatottak megjeleníteni. Bruce Springsteen a színpadon el is játssza, fel is eleveníti a munkássorsot, amit az otthont jelentő New Jersey-i miliőbe helyezett klipek vagy éppen a kedélyes közös italozásról szóló képek a látvány szintjén is kiemelnek. A dalokban az Amerikát keresztbe hasító nagy autós vándorlások vagy a fergeteges közös kocsmai táncok felelevenítése mindenkor az élettörténeti élmények megoszthatóságát húzza alá, ugyancsak ügyelve arra, hogy az énekes mint „egy a népből” a maga társadalmi gyökereihez való hűséget húzhassa alá. Mark Knopfler dalai elrugaszkodnak az életrajzi élményektől, amelyek közvetlenül legfeljebb látványokról, ízekről, filmkockákról szóló impressziókként, utalásokként tűnnek fel a szövegekben. Az elvonatkoztatás az élmény érvényének kiterjesztését szolgálja, a narrátor - az előadó - háttérbe húzódásával. Ez az eltávolítás egyúttal a konkrét lételemek másodlagosságát hirdeti az életformák közösségével szemben, és implicite megkérdőjelezi az előadó mint magánszereplő primátusát, jogalapját a kivételezettségre.

A fentiek fényében nem meglepő, hogy a három előadó háromféleképp tekint a közösségteremtés problémájára. Mint az egyéni utak bemutatásakor láttuk, a közösség formálódása mindhármuk számára többet jelent elkülönültségükben megszólaltatott csoportok puszta egymás melletiségnél. A közösségi minőség jelzi a beágyazottságot és a feloldódást, egyrészt az egyén kötődései felől, másrészt az egymástól elkülönülő csoportok szerves kapcsolódásával. Láttuk, bár a problematika közös a három előadó számára, megközelítéseik markánsan különbözőek.

Cseh Tamás számára az integratív keretet a nemzet jelenti: dalai a magyarul tudók közösségének szólnak, határon innen és határon túl. Ambíciója e közösség megtépázott egybetartozásának helyreállítása, ami mindenkitől elvárja a közösségi célok legalább egy részének feltétlen elfogadását. Megrajzolt közösségében a fennálló viszonyokkal szembeni távolságteremtés gesztusai tűnnek elő, és azok az ifjú hősök, akik mindegyre a határokat igyekeznek tágítani. Az egyénnek ugyanakkor nem sok tere látszik: ha kikerül a közösségből, elveszettnek és erőtlennek mutatkozik. A közösségi dalok nevelési célzatúak: az elbeszélésből kiemelt hős viselkedését mutatják meg elsősorban, hiszen ezt kívánja, ha a zenész példaképül szeretné állítani e hősöket a közösség elé. Közben a példakép viszonylagosságát - mintegy magyarázatot adva a kollektív hivatkozás lehetőségének töredezettségére és szakadáspontjaira - személyes sorsuk esendőségének ironikus felmutatása jelzi. 
Mark Knopfler hősei is esendőek, de ők egész életvitelükben és törekvéseikben valójában igazi antihősök, akiknek mindennapisága érdemel figyelmet. Körülöttük tágan értelmezett referenciacsoportjuk formálja az értékeket és a követendő magatartási mintákat, és ez a normatív fellépés sokszor hangsúlyosabb egyéni kvalitásaiknál. Mindez összhangban van Mark Knopfler történelemfelfogásával, amelyben a vezető, a kísérletező, próbálkozó szerep az egyéné, aki számára a közösség a bekapcsolódás lehetőségeit és tereit mutatja meg. A természete szerint hullámzó és időnként válságba jutó önértelmezés a közösséget fontos támasztéknak, megtartó erőnek tekinti. Az üzenet világos. Az értékeknek az egyén életében és gondolkodásában kell először helyükre kerülniük, s a közösség csak ebből építkezhet: befogad és feloldódást teremt, de az egyén munkáját sohasem pótolhatja, még kevésbé helyettesítheti. Éteri közösség cselekvő egyének nélkül nincsen.

Ez Bruce Springsteen egyénfelfogásának is a végső magva, bár az ő közösségei harcban állnak egymással. A fő megosztó erő a konformitás, aminek követése gátját szabja mind az egyén, mind közössége újító munkájának. A fő osztatok a rasszok és az eltérő generációs tapasztalatok mentén mutatkoznak: az összebékítés közösségi szinten egyelőre mindkét irányban illuzórikus. Ha pedig az, akkor a zenésznek e hasadások állandó felmutatása a feladata. A feladatkijelölés Springsteennél politikává formálódik: önmagát szószólónak tekinti, akinek nemcsak erkölcsi, de politikai feladata is a jogtalanságok és megfosztottságok elleni aktív fellépés.

Bár kevésbé az aktív politizálás követelménye, de a hang és erő híján önmagukért fellépni nem tudók képviselete mindhárom előadó ars poeticájának lényeges eleme. Mindhárman úgy látják, hogy a mögöttes összetartozást a legnyomatékosabban kulturális hivatkozásokkal érzékeltethetik. Így lesznek a történeti dalok, régi jazz- és blueszenék feldolgozásai a közösségi alapvetés megjelenítői Springsteennél, míg hasonló szerepet tölt be a Knopfler-dalokban a régi country-, blues- és soulzene az eredetet tisztán jelző, de attól mégis elrugaszkodó szerepeltetése, s hasonló a funkciója a magyar népzenei szöveg és dal felvonultatásának Cseh Tamás világában. A megerősítendő közösségiség mindhárom előadónál a zene legfőbb tárgya, bár a gyakorlati kivitelezés értelemszerúen különbözik. Springsteen a hagyományok átértelmezésére vagy e lehetőség híján hátrahagyására buzdít, Knopfler a magánéleti harmóniát és a tudatos értékválasztást sugallja, Cseh Tamás pedig harmóniában szeretné látni a hajdani paraszti hagyományokat és a városi életforma dalba emelt elemeit, a férfiszolidaritást, a törekvést a derüre és az egyéni bátorságot. A történelem mindhármuk keze alatt ellentmondásos anyag, s az egyénnek ezekre az ellentmondásokra reflektálnia kell. Az új hagyomány, amit épít, szelekción alapul: a múlt a jelenbe egyben át nem emelhető. A választásnak azonban el kell emelkednie a közvetlen létvilágtól, és a lehető legnagyobb ívben át kell fognia az egymás felé törekvőket, legyenek feketék egy fehér világban, vagy sűrű élettapasztalatokkal rendelkezők a pályára most lépő fiatalokkal szemben. Közösség és egyén teljes összecsiszolódása csak tendenciájában lehetséges. Innen nézve a dalok befejezetlenek. De a mozgató törekvés töretlen marad: a küzdő egyén mögött mindegyre ott a támasztó közösség, még ha az ideálishoz képest csak töredékesen is. Ez a képlet széles tömegek számára ismert - talán nem tévedünk, ha elsődlegesen ennek tudjuk be a három zenész hallatlan népszerűségét. Dalaik a szövegben és a hangzásban is követik az egyént küzdelmeinek útján, és a lezáratlansággal egyszersmind kifejeznek egy másik korlátot is: az egyén néha túlnő a közösségén, és keresgélése magányba és a megoszthatatlanság fájdalmába torkollik. E fájdalom zenei ábrázolása a bluesok világába nyúlik vissza. Ez a közös zenei hagyomány, ha másként és másként bánnak is vele, a három zenészt egybekapcsolja. Springsteen jobbára újrahangszereli a régi bluesdalokat, de megtartja azokat eredeti formájukban; Knopfler számára a blues a saját nyelvének alakításához felhasznált termékeny kiindulás és háttér; Cseh Tamás számára pedig fóként hivatkozás, idézet egy másik világból, ami sokak számára álmodozás és sóvárgás tárgya, de közvetlenül sohasem válik a dalok valós anyagává. 
Ahogy a közösségiség közös eszmeisége mellett a megidézett közösségek igen-igen sokfélék, úgy talán még nagyobb a változatosság a megénekelt egyének között. Cseh Tamás az indián játékok ihletére küzdő, férfias férfiakat ábrázol, akik számára mindenkor van értelmezhetősége a hősi tettnek. Ha a hajdani vitéz szétitta is az eszét, azért tud mondani néhány fontosat emberi tartásról és kitartásról; ha alkoholos gőzében hallucinál is, vagy ha éppen belefeledkezik egy harmonikusnak tűnő, a régmúltba veszett otthon felidézésébe, mindenkor ott a megcsúszás veszélye, s már magában a talpon maradás is teljesítmény. Mark Knopfler férfifigurái nem kevésbé esendőek, de mélyebben és személyesebben élik át a partszélre sodródás megsemmisító élményét. Meg is fogalmazzák a megkapaszkodás lehetetlenségét és a belátás nyomán születő elveszettségüket. Bruce Springsteen palettáján ott a bűnöző, de ott a régi táncokat frenetikus előadásmódban felidéző ifjú ember is, és ott vannak a fejlődésből kihagyottak, a kisodródók, akik számára az „amerikai álom” mások tündérmeséje, nekik maguknak azonban nemigen jut belőle.

Ez a sokféle esendő ember mind valamiféle feloldozást várna, s annak hiján beleragad a vágyakozásba és a tervezésbe. Springsteen a búskomorság ellenében legalább ideig-óráig enyhet nyújtó mulatságot kínál a számukra. Mark Knopfler esendő emberei csak visszahúzódni tudnak. A szerelem talán gyógyírt hozhatna, de megkeseredett tapasztalataik birtokában csak botorkálva próbálkoznak. Cseh Tamás ifjú férfiai számára egyfelől ott a gyerekkorba való visszavágyódás panaceája, másfelől az igazi férfimulatságok: az indián fegyverek készítése és e príma darabokkal a vadászat, a trófeák gyűjtése. Ezek mellett a férfiak mellett ritkán látunk asszonyokat, az ő életviláguk vagy elő sem túnik, vagy felolvad a férfiakéban. Az asszonyok mindig partnerek, és nemigen kezdeményeznek. De elérni őket a férfiaknak igen nehéz, a csalódástól, a megcsúszástól való félelem gúzsba köti a kezdeményező készségüket. Ha eltúnnek a nemek - leggyakrabban Knopfler dalaiban -, akkor a közös sors, a közösen megélt sebekre a gyógyír keresése emeli be a dalokba magát az elveszett vagy elveszettségét félő párt.

A közösségek irányába a férfiak törekednek - mintha ők a nőknél jobban tudnák, hogy odatartozásuk és beágyazottságuk egymagukban nem megteremthető és nemigen lehet megőrizni sem azt. Innen az áhítozás a férfibarátságokra, amelyeknek keretet és alapot a közös zenélés teremt. A három zenész nagy kincsként vigyáz e barátságokra mint a közösség felé vezető út legigazabb támpontjaira. De a barátságok nem helyettesítik a szerelmi élményt, ami maga is sokféle. Cseh Tamás világában disszidálás és abortusz rombolja, Mark Knopfleréban a feloldhatatlan magány, és Bruce Springsteenében a túl gyors élet sodrása, amit viszont a kegyetlen versengés hajt mindegyre előre. Magukban nézve, a három előadó férfiszereplői mindig tökéletlenek és mindig kielégítetlenek. Csak a közösségi relációk előterében mutatható meg tökéletlenségük és kielégítetlenségük forrása: a gyenge beletartozás, ami az egyik legfélelmetesebb az individuumra leselkedő veszélyek közül.

Ha fentebb a közösségi odatartozás iránti folytonos keresésről szóltam, akkor annak hajtóerejét itt leljük meg, a megkapaszkodás és a feloldódás iránti csillapíthatatlan vágyban, ami így vagy úgy, de a modern embert mint individuumot általánosan sújtja - és persze sarkallja is. Mark Knopfler ennek szomorúságát, Springsteen az egyént felemelni tudó személyes energiákat, Cseh Tamás pedig a kitörést mindegyre gátló külső korlátokat énekli meg. De mindhárman ugyanoda lyukadnak ki: enyhülést, megoldást csak a kapcsolatokban lehet lelni, azok pedig nagyobb közösségek felé mutatnak. Az, hogy a nagyobb közösség támaszt és stabil igazodási pontokat nyújt-e, valóban egyén és közösség viszonyának kiérleltségén és az egybetartozás minőségén múlik. Az összetartozás tehát nemcsak a közösség, hanem az egyén felől nézve is alapszükséglet, de olyan alapszükséglet, amelynek a kielégítéséért folyamatosan és újra meg újra dolgozni kell. 
A három közösség nagyon különböző. Cseh Tamásé a rendszertől a hetvenes, nyolcvanas években egyre jobban elidegenedő fiataloké - főleg azoké, akik nincsenek igazán otthon a nagyvárosban, az albérletező vagy munkásszálláson élő ingázó munkásoké, illetve a fiatal diákságé. Springsteen kiinduló közege a nyugati parti hippik és kései örököseik világa, akik ha formálisan levetkezték is a hippikorszak díszleteit, jelentős részükben sosem lettek a konszolidálódott kapitalista világ igazi, azonosulni tudó támaszai, és velük együtt látjuk az elégedetlenségükben keserúvé váló keleti parti munkásokat, szintén belefáradva az ellenállásba, de lelkileg mindmáig távol maradva. Mark Knopfler közössége fiatal és középkorú értelmiségiekből és a kispolgáriságból legalább a kultúrában kitekinteni tudó kisvállalkozókból, banktisztviselőkből, ügynökökbőláll. Bár szociológiailag különböznek, csendes ellenállásukban rokonok e közösségek. Ellenállásuk egy új közösség keresésének felhajtóereje. Ez az új közösség válasz lehet a kritikákra és a negációkra, de hogy azzá váljék, némi mozgalmi munkára volna szükség nem-mozgalmi időkben. A lehetetlen kívánság leginkább Knopfler bánatos dalaiban lepleződik le, de ott van persze Cseh Tamásnál is, amikor a munkásszállás „a nők utáni rohangálás” színhelye lesz, vagy amikor belátjuk, hogy mai közegünkben nem sokat jelentenek már az egykor közösen megfigyelt „porzók és bibék”, és körülöttük az osztálykirándulás kalandja.

Az egyén mai kapcsolódásának a legfontosabb és legbiztosabb eleme a közös emlékezés, az egykori gondolatok, beállítódások és élmények megidézése. Csakhogy mindez a későbbi, már nem közös fordulatok fénytörésén szűrődik át, és transzformálódik. Ma már mást gondolunk egykori hippi önmagunkról vagy az iskolai ellenállásról és '56 forradalmi emlékeinek hajdani titkos őrzéséről. Az emlékek tehát részben összekötnek, de részben távolítanak. S ha a távolság túl nagyra nő, akkor ahhoz képest eltörpül a közös alap, s talán az összetartozás soha többé létre sem jön. Vagy ha létrejön, akkor új alapokon szerveződik, amiből meg ordítóan hiányzik az emlékek közössége, és amit kötőszövetként az kipótol ott, ahol az azonosulás megakad. Világos, a közösség keresése és vele az egyén feloldódásának megtalálása szinte egy kérdezz-felelek játék mintájára szerveződik és körkörösen halad. Türelem is kell hozzá, meg a kapcsolódás igazi akarása. De ezt nem mindig így látjuk. Úgy néz ki, Mark Knopfler dalainak hősei nem is igen ácsingóznak érte. Inkább visszahúzódnak magánberkeikbe és legszúkebb világuk kapcsolatait ápolják. Hangosan nem mondják ki, de éreztetik: nem bíznak a nagyobb közösségek támaszában, illetve nagy történelmi pillanatokhoz kötik vagy az életforma szintjére emelt kapcsolattartástól remélik azt. De „békeidőben” elvannak csendes magányukban és a magánéleti várakozásokban. S persze e csöndesebb és privátabb kapcsolatoknak is van összetartó erejük, bár szúkebb határmegvonással, mint a nagyobb közösségek megtartó erejében bízó egyének feloldódási törekvései.

Ha mindehhez hozzávesszük az összetartozás fentebb tárgyalt másik jelentését, a közönségek összekapcsolásának képességét, akkor felfogásaik minden különbsége ellenére, rokon törekvéseket fedezhetünk fel a három előadó között. Mindegyikük kihasít a maga nagyobb világából egy-egy szeletet, és újító módon rakja azt a helyére: párban és perben álló ellenzékieket Cseh Tamás, hippiket és későbbi leszármazottaikat Bruce Springsteen, korosztályokat és határokon átívelő, rokon középosztályi csoportokat Mark Knopfler. Ebben az értelemben, mint láttuk is, mindhárman hisznek a közösségi összetartozásban, amit a magánélet és az egyén feloldódási lehetőségei felől oly nagyon másnak érzékelnek, s amire nagyon más válaszokat is adnak. De fontos, hogy bár mindhármójukat jellemző célként tételeződik a csoportokon átnyúló közösségi egybefonódás előmozdítása, ezt inkább munkájuk remélt eredményeként, semmint kiindulásaként fogják fel. A dalokban ténylegesen ábrázolt közösségek egyelőre önmagukban álló alakulatok, amelyeknek sokszor a tökéletlenségei nyitnak kaput más, hasonlóan tökéletlen csoportok felé: legyenek akár parasztok és munkások Cseh Tamás dalaiban, szipuzó hippik és munka után lerészegedő melósok Springsteennél, vagy egymással párbeszédbe elegyedő könyökvédős hivatalnokok és öntelten zenélő amatőrök Mark Knopfler ábrázolásában. Hogy érzékeny 
pontokra tapintottak, azt éppen az egybefonódó közönségreakciók jelzik, amelyek értően visszaigazolják a felmutatott hiányokat és felcsillantják az egybeötvöződő reagálás többletét. Ez az élményközösség persze egyelőre csak befogad. De a közös ráismerés lassan talán a közös cselekvés alapjává is válhat - ami persze már túl van az egyes előadó kompetenciáján és cselekvési körén.

Végül kell még szólnunk zene és szöveg viszonyáról a közösségteremtő törekvésekben - részben a közösség zenéjéről, részben a zene szerepéről az egyéni útkeresésben és a kapcsolódási törekvésekben. Cseh Tamás egyszerű dallamvilága néhány jól megjegyezhető akkordra és azok ismétléses kibontására épül. Az ő dalvilágában a dalok jó része illusztráció: a kemény verssorokat van hivatva kiemelni és aláhúzni - legyen szó egy magánéleti problémáról vagy a közösség hangjáról. Szövegek nélkül ezek dúdolnivaló dallamok, nem túl nagy jelentőséggel. De mivel a nagy tehetségű előadó szájából jönnek, oda sem figyelünk arra, hogy kvalitásukban néha mekkora szakadék tátong szöveg és dallam között. A kiemelt helyek szövegükben és az előadó által hozzárendelt zenéjükkel együtt lesznek idézendő frázisok - egy közös emlékvilág megigézői és az összetartozás hangban is kifejezett, ismételve elénekelt megjelenítói.

Bruce Springsteen zenéjének feltétlen alapja a rock'n'roll, összhangban kora ifjúságától hangoztatott álmával, miszerint ő rock'n'roll király akar lenni. A rockos tempó jól illeszkedik a fő tematikát jelentő hippivilág rohanó képeihez, állandó úton levéséhez. Később a rocktörekvést aláhúzza a fúvósok szerepeltetése, ami viszont a fekete jazzelőzményekhez köti a zenét. Harmadik síkként ott a bluesok világa, aminek előterében lassúbb és bánatosabb gondolatok formálódnak az értékek zavaráról és az ország, benne a fiatal generációk csekélyre szorult politikai szerepéről, lehetőségeiről. A zene sokszor a színpadra vitt koreográfia kiszolgálója, sokszor a viszony fordított. De mindig kicsiszolt és nagyon igényesen megformált az összzenei hatás, kellő súllyal a különböző fúvósoknak és a színpadra a zongora mellől kipattanó tangóharmonikásnak, akik mind megcsillogtathatják briliáns hangszertudásukat, miközben gondosan ügyelve megmarad az előadás közössége és közös harmóniája. Bruce Springsteen a színpadon is úgy énekel, mintha egy kész lemezfelvétel forogna: minden hang és hangsúly a helyén, miközben azért marad játéktér az improvizációra. A zenekar mint közösség nem is törekedhetne nagyobb idill megvalósítására és az összemúködés magasabb fokára.

Hangzásvilágában a legbonyolultabb Mark Knopfler játéka. Miközben a rock'n'rollnak az ő zenei világában is jelentős szerepe van, itt magában csak ritkán szerepel. A rock ritmusa és gyors ütemú ismétlései összefonódnak a countryzenével és a blues- és soulhagyományból táplálkozó dallamokkal. Csak ritkán és alkalomszerűen szerepelnek eredeti formájukban: inkább ráutalólag, Knopfler saját szerzeményeibe épülve. A hűséges és régi kapcsolatokon nyugvó zenekarnak Mark Knopfler zenéjében ugyancsak kitüntetett szerep jut. Egyrészt a zenekar tagjainak széles hangszertudása megengedi, hogy magát a hangzást ki lehessen szélesíteni, s az ezáltal hívebben és csábítóbban invitáljon csatlakozásra. Másrészt a zenekar profi színvonalú és sokszínú játéka Knopflernél is enged az improvizálásnak, amivel még mozgalmasabbá varázsolja a zenei mondandót. Talán mondható, hogy sokrétegűsége és gyakran meditatív jellege miatt a hármasból Mark Knopflernél érzékeljük a legélesebben azokat a dilemmákat, amelyeket a dalok az összetartozás és közösségteremtés lehetőségeiről és nehézségeiről elénk tárnak. S amikor a dalok olyan erőre kapnak, hogy immár két teljes dobfelszerelés és két dobos szolgálja a mondandó ritmikai hátterét, akkor megérezzük ezeknek a dilemmáknak a súlyát és a velük szembeni tehetetlenségünket is. Itt a country mint a hajdani amerikai farmervilág közösségi zenélési formája áll előttünk, s a ráépülő ősi motívumok zenei felfejtése a modern világba deponálja a máskor kissé ódivatúnak tartott zenét. A kibányászható hagyományok egyfelé mutatnak, az egyén közösségi beágyazódását és a közösségiség kifejezhető formáit keresik. És itt a szöveg és a zene összeér: a dalok a lepusztuló kapcsolatok kibontását és egy más minőségben való újbóli összefúzésük lehetőségeit járják körbe, akár az elérni vágyott 
világ távolsága, akár a meglelt közelség kifejezésének útján. A dalok ettől súlyosak lesznek, nem engednek a Springsteen-féle felpörgésnek. Mindegyikük egy-egy válasz a fentebb kibontott dilemmára, egyén és közösség viszonyára. Persze ezek a különbségek a zenében azt is kifejezik, hogy a dilemma feloldásának többféle útja van, s ezek között mi magunk, a közönség válogathatunk. De kifejezik elhagyatottságunkat is, és azt, hogy ezzel az elhagyatottsággal mennyire akarunk vagy tudunk szembenézni. Végső soron a választás szabadsága, de a felelősség is a miénk.

A három zenész ehhez a muníciót szolgáltatja, de nem veheti magára az egyén döntésének terhét. Éppen elég, hogy az elmúlt évtizedekben kiszabadította a könnyúzenét a bárgyú táncdalok szirupba zártságából, és megteremtette a kifejezés sokszínű formáit. Ezzel pedig egy új múfajt alapított: a komolyan vehető és komolyan veendő könnyűzenét, benne szólót éneklő-játszó előadók és zenekaraik sokféle viszonyával. Mint láttuk, a sokféleség képes megjeleníteni igazodásunk és a közösségbe való feloldódásunkra irányuló válaszaink hol konvergáló, hol széttartó pályáit és sokféle tartalmát. És ebben éppen olyan a teljesítménye, mint bármely más, fontos zenei tradíciónak. Nekünk, a közönségnek pedig egy új, a választásainkat kiterjesztő közeget teremt. S bár választásaink különböző közösségekre vonatkoznak, a három előadó zenéje még akkor is átjárhatóságokat teremt, ha szövegeik épp e külön közösségeket hansúlyozzák. Ez pedig biztosítja, hogy erkölcsi normáik és az egyén feloldódásából következő, egymástól különböző törekvéseik mellett a befogadó közeg nagyobb átfogó ereje születhessen meg. Ez a nagyobb integráció a nyugati emberek közössége, akiknek állást kell foglalniuk háború és béke, magány és feloldódás, egyéni virtus és szolidaritás alapvető kérdéseiben. Ezzel a zene kiszabadul a mégoly közösségivé érlelt, de partikuláris közösségre szabott kereteiből, és elemel a modern világ általánosabb kérdései felé, ahol a dilemmákra a választ már a zenén túl nekünk magunknak kell megtalálnunk. 